\title{
Career Competencies of Human Resource Development Practitioners*
}

\author{
Yong-Ho PARK**
}

Received: February 3, 2020 Revised: February 24, 2020 Accepted: March 6, 2020.

\begin{abstract}
The study aims to define the career competency of HRD practitioners based on an intelligent career framework. This intelligent career framework has been described as having been achieved by the accumulation of career capital through the three ways of knowing, including knowing why, knowing how, and knowing with whom. The data were collected from the interviews with 15 HRD practitioners. Semi-structured interviews were used to collect data from the HRD practitioners. For the orientation about the interview, the researcher explained the importance of gathering data about the personal experiences of the respondents on their work and career. After that explanation, the researcher asked several questions based on the pre-structured interview guide. The data collected were qualitatively analyzed on the basis of the intelligent career framework. Based on the analysis of the interviews, the subcategories of each way of knowing competency were identified. For the knowing why, identity, credibility, and career clarity were identified. The subcategories of knowing how are remaining updates, hard skills, and soft skills, while the subcategories of knowing with whom are personal networking and professional networking. The interdependency among the three career competencies was found. The findings provide theoretical implications of applying an intelligent career framework.
\end{abstract}

Keywords : Intelligent Career, Career Competency, Three Ways of Knowing, HRD

JEL Classification Code : M12, M53, M54

\section{Introduction}

The career environment has been rapidly changed through various new work arrangements, as well as nature of work, diverse workforce, and organizational structure changes. Career path has been regarded traditionally as an upward movement in one organization; however, various mobilities have replaced that one-way career movement (Lee \& Kim, 2019; Mustapa, Noor, \& Mutalib, 2018). Now, the unpredictability of "new careers" has emerged (Arthur, Inkson, \& Pringle, 1999).

*This study was supported by Incheon National University Research Grant.

**First Author and Corresponding Author. Associate Professor, Department of Creative Human Resource Development, College of Social Science, Incheon National University, Korea [Postal Address: 119 Academy-ro, Yeonsu-gu, Incheon, 22012, Korea] Tel: +82 032835-8165, Email: yhpark@inu.ac.kr and yxp122@gmail.com

(c) Copyright: The Author(s)

This is an Open Access article distributed under the terms of the Creative Commons Attribution Non-Commercial License (http://Creativecommons.org/licenses/by-nc/4.0/) which permits unrestricted noncommercial use, distribution, and reproduction in any medium, permits unrestricted noncommercial use,
provided the original work is properly cited.
Several career perspectives related to the new career include boundaryless career, protean career, and intelligent career (Arthur \& Rousseau, 1996; DeFillippi \& Arthur, 1994; Hall, 1996, 2002). These new careers underscore an individual's self-directedness, utilize career development opportunities, and establish career competency. Since the responsibility of an individual in the management of his/her own career is critical for career success, investing and developing career competencies are important for the modern career era (Cappellen \& Janssens, 2005; Dickmann \& Doherty, 2008; Dickmann \& Harris, 2005; Dickmann \& Mills, 2010; Hall, 2004; Sturger, Simpson, \& Altman, 2003).

In regard to the investment and development of career competency, DeFillippi and Arthur (1994) argued that individuals need to be a "career capitalist" in order to acquire career competencies for their career success. In the intelligent career theory of DeFillippi and Arthur involving the application of intelligence enterprise (Quinn, 1992) to an individual's career investment, they proposed that individuals invest in their career through the three ways of knowing. The three ways of knowing, which are recently 
updated, are knowing why, knowing how, and knowing with whom (Arthur, Khapova, \& Richardson, 2017). The previous literatures regarded these three different ways of knowing as the key aspects of career competency and these have been studied in various environments (Cappellen \& Janssens, 2008; Colakoglu, 2005; Dickmann \& Mills, 2010; Parker, Khapova, \& Arthur, 2009; Suutari \& Mäkelä, 2007).

Even though there are several studies on intelligent career, there are only a few literatures on the human resource development (HRD) field. Furthermore, there is a limited number of studies performed on the career competency of HRD practitioners. HRD practitioners are the key persons who are responsible for developing the competency of the employees. However, they often neglected to improve themselves in the workplace. In light of the above statement, this study aims to define the career competency of the HRD practitioners based on an intelligent career framework. In particular, this study tries to find the three ways of knowing competencies of the HRD practitioners, and the interdependency among them. The discussion on the results of this study may show the theoretical and practical implication for developing career competency.

\section{Literature Review}

\subsection{Intelligent Career}

DeFillippi and Arthur (1994) initially developed the intelligent career theory and it was revised and re-labeled by Arthur, Claman, and DeFillippi (1995). This intelligent career theory is based on the boundaryless career discourse. It also adopts Quinn's idea of an 'intelligent enterprise' having core elements, such as culture, know-how, and networks in a knowledge-driven era. According to DeFillippi and Arthur (1994), intelligent career is the competency-based approach to career success. They argued that individuals need to take responsibility for their own careers, and this argument was further discussed through the following studies in relation to intelligent careers, protean career, boundaryless career, and other new career concepts. This intelligent career theory has been described as having been achieved by the accumulation of career capital through the three ways of knowing, including knowing why, knowing how, and knowing with whom (Arthur, Claman, \& DeFillippi, 1995).

According to DeFillippi and Arthur (1994), an individual can be a career capitalist through the accumulation of career competencies. They identified accumulation as being dependent on not any one organization, but the whole course of an individual's career. In addition, they argued that the career capital can be accumulated not only by one competency, but also through the interdependency of the three ways of knowing competencies. This interdependency comes from the six two-way relationships between each pair of career competencies. In the theory of intelligent career, people need to invest in their careers through the aforementioned three ways of knowing (Arthur, Khapova, \& Richardson, 2017; Parker, Khapova, \& Arthur, 2009). These reflect an individual's identity and purpose (knowing why), expertise and skills (knowing how), and social network and reputation (knowing with whom). The following sections explain those three competencies respectively.

\subsection{Knowing Why}

The knowing why refers to the identity, personal meaning, motivations, self-concept, value, interest, and sense of purpose that are invested in pursuing a career (DeFillippi \& Arthur, 1994; Parker, Khapova, \& Arthur, 2009). This competency may be the answer to the critical question, 'Why do you work?' Career counseling approaches that mainly distinguish and examine individual differences have discussed the knowing why for a long time. This competency is usually expressed as the 'ambition to pursue personal meaning in the workplace,' or 'seeking a balance for taking care of my family'.

According to previous studies, the knowing why can be changed and developed (Yoon, Kim, \& Eom, 2019). Recently, this argument has been identified in the discussion on the meaningful work (Duffy, England, \& Dik, 2019; Steger, 2019). DeFillippi and Arthur (1994) wrote that an individual's knowing why may change toward a hope to influence others, or to become a mentor for others. In his career construction theory, Savickas (2005) argued that an individual's knowing why constantly changes as the career environments change. He suggested a contextualist perspective on careers. In this perspective, personal development is seen not as the maturation of inner characteristics, but as the process of adaptation to a career environment. He also argued that identity shifting could happen through the evolving experience of changes in career readiness and adaptability.

\subsection{Knowing How}

The knowing how closely reflects the human capital theory, underlining the importance of formal education and informal workplace learning (Becker, 1964). The knowing how answers the question, 'How do you work?' Behaviors related to increasing this competency includes the development of skills, knowledge, and expertise that are essential for a successful performance (Beigi, Shirmohammadi, \& Arthur, 2018). In today's knowledge 
economy era, the continuous development of knowledge and skills is needed for workplace success. In particular, if continuous development goes beyond job demands, individuals may increase their knowing how and enhance their own employability (Inkson \& Arthur, 2001; Fugate, Kinicki, \& Ashforth, 2004).

This knowing how can be organization-specific or potentially transferable across boundaries to different organizational situations (Inkson \& Arthur, 2001). Since it is a transferable and flexible skill, the knowing how is different from formal education or training. As technologies develop, the focus of knowing how continues to shift to new rising opportunities. It is therefore essential to understand the industries and the market in order to become equipped with this knowing how. Knowing how can be developed through a combination of explicit knowledge from a program or book and tacit knowledge (Nonaka \& Takeuchi, 1995). Tacit knowledge is the know-how that individuals know but find it difficult to tell (Polanyi, 1962) the skills and expertise of various craft occupations.

\subsection{Knowing with Whom}

Knowing with whom is related to relationships and reputation that are accumulated though interactions not only with bosses, peers, and subordinates in the workplace, but also with nonwork contacts, including family relations, friends, and other acquaintances. Knowing with whom may reflect an individual's reactions to the question, "With whom do you work?" (Inkson \& Arthur, 2001)

This knowing with whom is transferable from one employee context to another (Zikic \& Ezzedeen, 2015). Through the relationships with those people, an individual is able to have the means to exchange information and build rapport. (Chang \& Kim, 2018; Parker, Khapova, \& Arthur, 2009). In regard to the knowing with whom, the theoretical background came from several social capital theories, including role modeling, social networking, mentoring, developmental relationship, community of practice, etc. Based on these theoretical backgrounds, an individual's career is considered to be formed and developed in unique contexts (Beigi, Shirmohammadi, Arthur, 2018).

\subsection{Interdependency among the Three Career Competencies}

The three ways of knowing are connected with one another (Inkson \& Arthur, 2001). According to Parker, Khapova, and Arthur (2017), careers were developed through the interdependence among these competencies. In regard to the relationship among these competencies, examples of such interdependence include meeting new friends through the current job (knowing how to knowing with whom), receiving helpful encouragement from coworkers (knowing with whom to knowing why), and enjoying the experience of the job itself (knowing how to knowing why competency). The current study seeks to investigate the accumulation of the career capital of the HRD practitioners. As a result, the relationships among these three competencies will be analyzed through qualitative interview data.

\section{Methods}

In order to examine the career competencies of HRD practitioners, the current study used a qualitative data collection method for acquiring the career behavior and attitude information of an individual. Based on the remarks of the respondents regarding their own career, the stories about the career competencies of HRD practitioners were gathered.

\subsection{Participants}

In order to determine the study results, 15 HRD practitioners were interviewed. These 15 practitioners had worked for Korean conglomerates. The majority of the interviewees were male $(n=9)$ and the average age of the interviewees was 43.8 years. The average career age of the interviewees as HRD practitioners were 10.2 years.

\subsection{Data Collection}

Semi-structured interviews were used to collect data from the HRD practitioners. For the orientation about the interview, the researcher explained the importance of gathering data about the personal experiences of the respondents on their work and career. After that explanation, the researcher asked several questions based on the prestructured interview guide, such as "Could you tell me more about your career? Could you tell the story of your journey to your current position? What do you think is your most critical motivation for working at the workplace? What resources do you use at the workplace to develop your career? Why is your differential experience important to you and how did it come about?".

\subsection{Analysis}

The interviews were recorded for the following analysis, and the recordings were transcribed. The collected interview data were analyzed through the intelligent career framework, which is composed of knowing why, knowing how, and knowing with whom. In order to analyze the data, the researcher read the transcripts several times and coded the 
quotations in reference to the intelligent career framework. If the coded quotations are related to meaning and values, those were coded as knowing why. Job-related knowledge and skill were coded as knowing how, while social contacts and relationship were coded as knowing with whom. During this coding process, the researcher adds, merges, and deletes the codes in reference to the previous studies. Through this process, the researcher is able to group and label the subcategories based on the three competencies model of an intelligent career.

\section{Results}

\subsection{Three Ways of Knowing}

Based on the analysis of the three career competencies, the section below describes the subcategories that are relevant to each way of knowing and the six links identified among the three ways of knowing. Each link provides the supporting quotations from the interview transcripts. Through the analysis on the interviews, the subcategories of each way of knowing competency were identified. For the knowing why, identity, credibility, and career clarity were identified. The remaining updates, hard skills, and soft skills were subcategories of knowing how. Lastly, personal networking and professional networking were the subcategories for knowing with whom.

\subsection{Why to How}

The analysis showed several pathways from why to how. The fact that the career identity of the HRD practitioners in the labor market paved the way for preparing hard skills and soft skills was identified in the interviews. One of the HRD practitioners stated that finding his career identity provided him with opportunities to enhance his hard skills, as stated below:

I have been an HRD specialist for about 11 years. I have found my identity even though I did not realize my career identity at the beginning of my career. With my career identity as an HRD practitioner, I tried to hone my knowledge and skills related to that job.

In addition, recognizing what they really want from their own career (career clarity) has had an influence on remaining updated in the workplace, and developing hard skills and soft skills, as stated below:

I have done several different HR-related jobs in three different organizations. When I started working as an HRD specialist in this company five and a half years ago, I realized that my career had hope. After that, I sought to hone my knowledge and skills that are utilized in HRD fields, such as training program designing, creating delivering methods, and people managing skills outside of organization learning opportunities.

\subsection{Why to Whom}

In regard to the relationship from knowing why to knowing with whom, the analysis on the transcript of HRD practitioners showed that finding career identity is a critical influential factor for developing professional network, as stated below:

After working for 7 years in the HRM and HRD fields, I knew that this is the right job for me, so I started to seek the outside network from 2 years ago. Since I am hoping to become an HRD professional, I think that I will be needing those networks for my career.

Furthermore, HRD practitioners pointed out the development of professional networking behaviors to build a career credibility that is perceived by colleagues, bosses, and employees. One of the female HRD practitioners described that relationship in the following quote:

As a female HRD practitioner, I wanted to show my expertise in the previous male-dominated company. In order to recognize my professional achievements, I participated in a community of practice that is composed of more experienced HR professionals.

\subsection{How to Why}

The analysis on the interviews of the HRD practitioners showed several pathways from how to why. The results showed that the remaining updated knowledge and skills has a positive relationship with understanding career identity and clarity. The following quotation is about the relationship between the remaining updates and career identity:

As a senior manager of the HRD function of my company, I need to learn and apply the recent tradition into practice. I enjoyed updating my expertise as an HRD practitioner. However, I realized that I want to do my job more actively, and not just manage or make plans on the desk.

Several HRD practitioners stated that developing hard skills related to the current job, HRD practitioner, provided them with opportunities to understand the career clarity. The following quotation is from a practitioner who was an electronic engineer with 4 years of experience in working as an HRD practitioner: 
Four years ago, I changed my job from an engineer to an HRD practitioner. This field was very new to me at that time, so I tried to learn HRD-related knowledge and skills, including action learning, training design, smart learning, etc. Through this process, I was hopeful that I would become a professional in this field, and I clearly knew that I am well suited to this field.

\subsection{How to Whom}

The relationship between how and with whom is most frequently identified in the analysis. The fact that the HRD practitioners sought to build professional network was identified in order to develop hard skills and soft skills, and keep the recent knowledge and skills. The following quotations are about the effects of knowing how on the seeking professional networks:

I wanted to equip myself with recent knowledge and skills for my career development. It doesn't matter whether I am an HRD practitioner or not. I wanted to become a professional. Each month, I planned to meet a new person outside of the company. I have been doing this for almost 3 years, and I could accumulate my social capital.

As an HR related field practitioner, I needed to enhance my expertise. Therefore, I started to study my master's degree in psychology this year. I learned from professors in the classrooms. However, I learned a lot from the colleagues in the same program. They are working in consulting firms or other big companies. I have had more hands-on experience from various professionals.

\subsection{Whom to Why}

In this study, the knowing with whom has two subcategories, namely, personal and professional network seeking. Only two respondents referred to their personal network beyond business organizations. They pointed out that the personal relationship could be the way to recognize their own identity, as stated below:

I can still recall my old dream involving my relationship with my old friend. His recommendation to reconsider teaching has given me a great opportunity to change my job. Even though I am not working for a school, I am currently doing a job developing others.

In regard to the professional networking of HRD practitioners, several respondents stated that social capital is able to enhance career identity, credibility, and career clarity. In other words, professional network has a relationship with all the three subcomponents of knowing why. The relationship with career clarity is shown below:

My mentor, whom I met in the previous company, suggested doing a slightly different job from the current HRD position. His advice is applicable to the current company's business environment. Now, I am waiting for movement to mark the position in this company. I was not sure of the vertical movement with the HRD position.

\subsection{Whom to How}

Building the network with a professional in and out of the organization can pave the way for the know-how in doing a job. The respondents showed the relationship between whom and how, as shown below. They pointed out the importance of building professional network both inside and outside of the company:

In order to become a professional in the workplace, I think the most important thing is to learn from a more experienced person. In particular, I think a more experienced person in my company is a very useful source for developing workrelated competency and human skills.

A resource person is very critical for being a professional. I met an HRD consultant during a competency modeling project for my company department leader. I have learned from him so much, not just the competency modeling, but also the recent trends of the HRD field. Those are very helpful to me.

Figure 1 shows the three competencies and interrelationships among those competencies based on the study results.



Figure 1: Career Capital of HRD Practitioners 


\section{Discussion and Conclusion}

This study aims to investigate the career competency of the HRD practitioners based on the intelligent career framework. It is composed of the three ways of knowing, such as knowing why, knowing how, and knowing with whom. The study results showed the subcategories of each way of knowing. Some of these subcategories are very similar to the previous studies (Beigi, Shirmohammadi, \& Arthur, 2018; Cappellen \& Janssens, 2003; Sturges, Simpson, \& Altman, 2003). The subcategories for knowing why are identity, credibility, and career clarity. The subcategories for knowing how are remaining updates, hard skills, soft skills, and the subcategories for knowing with whom are personal networking and professional networking.

On the basis of the study results, the following theoretical and practical implications may be suggested. First of all, this study provided the evidence for the six links among the three ways of knowing through the analysis on the data from the HRD practitioners. Even though the intelligent career theory has been discussed in career literature, there are limited studies showing the interdependency among the three competencies (Beigi, Shirmohammadi, \& Arthur, 2018). This study results tried to provide research evidence for the intelligent career framework. With qualitative (Sturges, Simpson, \& Altman, 2003) and quantitative (Beigi, Shirmohammadi, \& Arthur, 2018; Born \& Witteloostuijn, 2013; Zikic \& Ezzedeen, 2015) studies on the interdependency among the three ways of knowing, this study showed another evidence of the links of knowing why, knowing how, and knowing with whom.

Moreover, among the six links between the two career competencies, this study showed that some of the links were more critical. For example, the study results showed that the relationship between knowing how and knowing whom is most frequent in the analysis. In other words, HRD practitioners tried to build a professional network for developing hard and soft skills. This difference in the frequency or importance need to be considered in order to use the intelligent career framework practically in the workplace. Furthermore, this study collected interview data from the HRD practitioners. As the employees are taking charge of developing others, they may need to develop themselves firstly. This study showed how the human resource developers could be developed through the practical accumulation of the competencies, especially the fact that the study results identified not only the traditionally accepted as competency, such as know-how, and relationship, but also understood that self and direction will be helpful for a wholistic approach in developing HRD practitioners.

Despite those theoretical and practical implications, there are several limitations in this study, such as limited career background and demographic background on the participants (all interviewees came from Koran conglomerates). Future studies may include a more comprehensive data from diverse samples for investigating the intelligent career framework.

\section{References}

Arthur, M. B., \& Rousseau, D. M. (1996). The Boundaryless Career: A New Employment Principle for a New Organizational Era. New York, NY: Oxford University Press.

Arthur, M. B., Claman, P. H., \& DeFillippi, R. J. (1995). Intelligent enterprise, intelligent career. Academy of Management Executive, 9(4), 7-20.

Arthur, M. B., Inkson, K., \& Pringle, J. K. (1999). The New Careers: Individual Action \& Economic Change. London, UK: Sage.

Arthur, M. B., Khapova, S. N., \& Richardson, J. (2017). An Intelligent Career: Taking Ownership of Your Work and Your Life. London, UK: Oxford University Press.

Becker, G. S. (1962). Investment in human capital: A theoretical analysis. Journal of Political Economy, 70, 9-49.

Beigi, M., Shirmohammadi, M., \& Arthur, M. (2018). Intelligent career success: The case of distinguished academics. Journal of Vocational Behavior, 107, 261-275.

Cappellen, T., \& Janssens, M. (2005). Career paths of global managers: Towards future research. Journal of World Business, 40(4), 348-360.

Cappellen, T., \& Janssens, M. (2008). Global managers' career competencies. Career Development International, 13(6), 514537.

Chang, J., \& Kim, T. (2018). Looking at organizational socialization from the developmental network perspective. Journal of Asian Finance, Economics and Business, 5(3), 195206. http://doi.org/10.13106/jafeb.2018.vol5.no3.195

Colakoglu, S. N. (2005). The relationship between career boundarylessness and individual well-being: A contingency approach (Doctoral dissertation). Drexel University, Philadelphia, Pennsylvania.

De Fillippi, R. J., \& Arthur, M. B. (1994). The boundaryless career: A competency-based perspective. Journal of Organizational Behavior, 15(4), 307-324.

Dickmann, M., \& Doherty, N. (2008). Exploring the career capital impact of international assignments within distinct organizational contexts. British Journal of Management, 19(2), 145-161.

Dickmann, M., \& Harris, H. (2005). Developing career capital for global careers: The role of international assignments. Journal of World Business, 40(4), 399-408.

Dickmann, M., \& Mills, T. (2010). The importance of intelligent career and location considerations: Exploring the decision to go to London. Personal Review, 39(1), 116-134.

Duffy, R. D., England, J. W., \& Dik, B. (2019). Callings. In R. Yeoman, C. Bailey, A. Madden, \& M. Thomas (Eds.), The Oxford Handbook of Meaningful Work (pp.274-287). Oxford, UK: Oxford University Press.

Fugate, M., Kinicki, A. J., \& Ashforth, B. E. (2004). 
Employability: A psycho-social construct, its dimensions, and applications. Journal of Vocational Behavior, 65(1), 14-38.

Hall, D. T. (1996). Protean careers of the 21 st century. The Academy of Management Executive, 10(4), 8-16.

Hall, D. T. (2002). Careers in and out of Organizations. Thousand Oaks, CA: Sage.

Hall, D. T. (2004). The protean career: A quarter-century journey. Journal of Vocational Behavior, 65(1), 1-13.

Inkson, K., \& Arthur, M. B. (2001). How to be a successful career capitalist. Organizational Dynamics, 30(1), 48-61.

Lee, W.-S., \& Kim, B.-Y. (2019). The effects of career orientations on entrepreneurial satisfaction and business sustainability. Journal of Asian Finance, Economics and Business, 6(4), 235248. https://doi.org/10.13106/jafeb.2019.vol6.no4.235

Nonaka, I., \& Takeuchi, H. (1995). The Knowledge-creating Company. New York, NY: Oxford University Press.

Mustapa, N. S., Noor, K. M., \& Mutalib, M. A. (2018). Why can't we have both? A discussion on work-life balance and women career advancement in Malaysia. Journal of Asian Finance, Economics and Business, 5(3), 103-112. http://doi.org/10.13106/jafeb.2018.vol5.no3.103

Parker, P., Khapova, S. N., \& Arthur, M. B. (2009). The intelligent career framework as a basis for interdisciplinary inquiry. Journal of Vocational Behavior, 75(3), 291-302.

Polanyi, M. (1962). Personal Knowledge: Towards a Post-critical Philosophy. London, UK: Routledge \& Kegan Paul.

Quinn, J. B. (1992). Intelligent Enterprise. New York, NY: Free
Press.

Savickas, M. L. (2005). The theory and practice of career construction. In S. D. Brown, \& R. W. Lent (Eds.), Career Development and Counseling: Putting Research and Theory to Work (pp.42-70), Hoboken, NJ: Wiley.

Steger, M. F. (2019). Meaning in life and in work. In R. Yeoman, C. Bailey, A. Madden, \& M. Thomas (Eds.), The Oxford Handbook of Meaningful Work (pp.208-220). Oxford, UK: Oxford University Press.

Sturges, J., Simpson, R., \& Altman, Y. (2003). Capitalising on learning: An exploration of the MBA as a vehicle for developing career competencies. International Journal of Training and Development, 7(1), 53-66.

Suutari, V., \& Mäkelä, K. (2007). The career capital of managers with global careers. Journal of Managerial Psychology, 22(7), 628-648.

Yoon, K.-H., \& Kim, B.-Y., \& Eom, J.-G. (2019). The effects of job crafting on career success of multinational corporation's employees. Journal of Asian Finance, Economics and Business, 6(4), 213-225. https://doi.org/10.13106/jafeb.2019.vol6.no4.213

Zikic, J., \& Ezzedeen, S. (2015). Towards a more integrated view of entrepreneurial careers: Qualitative investigation of the three forms of career capital and their relationships among high tech entrepreneurs. International Journal of Entrepreneurial Behavior \& Research, 21(6), 756-777. 